Supplement of Hydrol. Earth Syst. Sci., 18, 3937-3950, 2014

http://www.hydrol-earth-syst-sci.net/18/3937/2014/

doi:10.5194/hess-18-3937-2014-supplement

(C) Author(s) 2014. CC Attribution 3.0 License.

(c) (1)

Supplement of

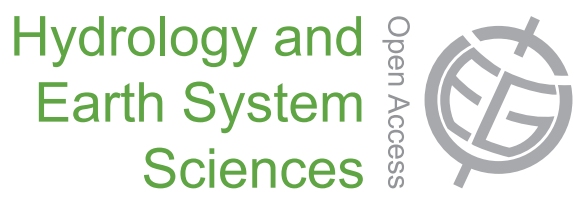

\title{
Variability of moisture recycling using a precipitationshed framework
}

P. W. Keys et al.

Correspondence to: P. W. Keys (patrick.keys@su.se) 


\section{Precipitationshed persistence for MERRA}

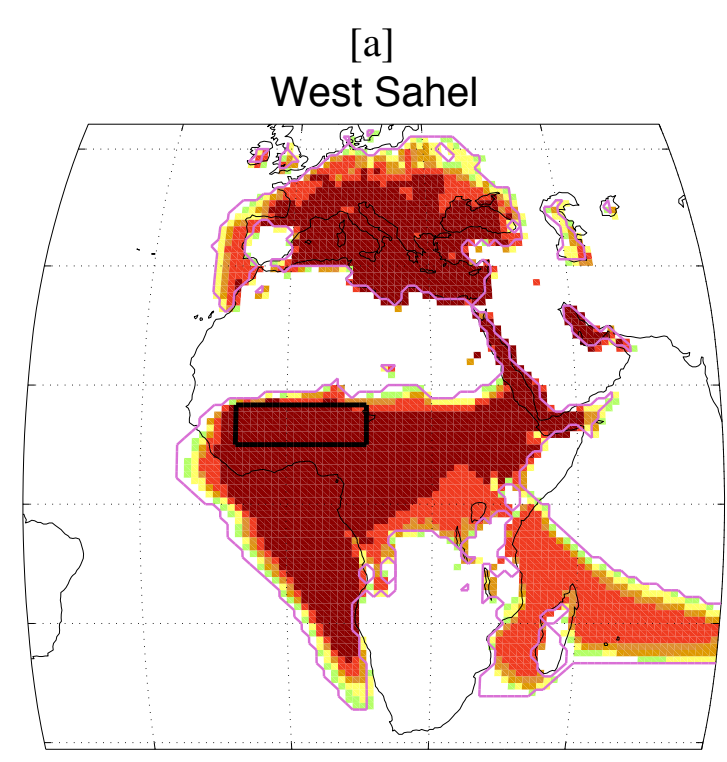

[b]

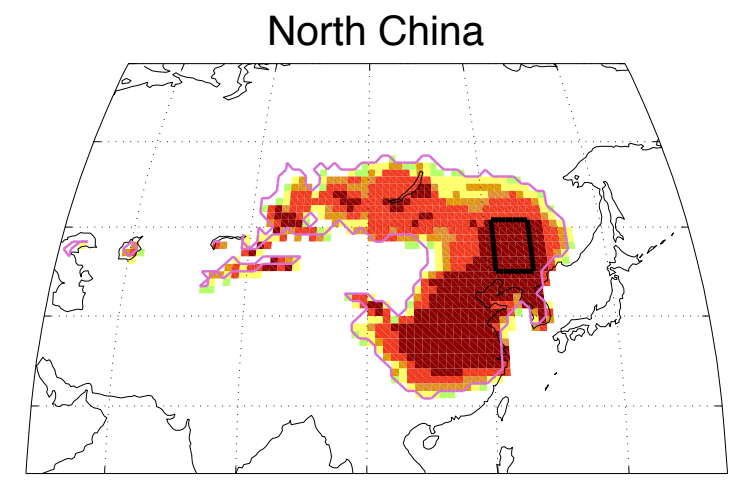

[c]

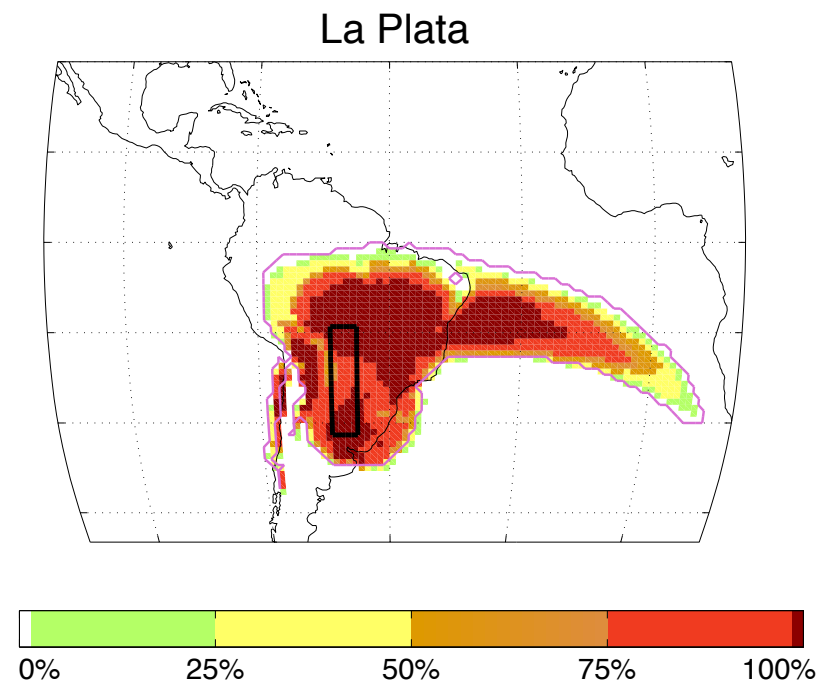

Fraction of years grid cell is in precipitationshed

Fig. 1. The persistence of the Western Sahel, Northern China, and La Plata precipitationsheds for MERRA for the years 1980-2011. "Significant' is defined as greater than $5 \mathrm{~mm}$ growing season ${ }^{-1}$, and the dark red areas correspond to the core precipitationshed, with significant contribution occurring during $100 \%$ of growing seasons. The black boxed areas are the sink regions for each precipitationshed. 